\title{
Heat coagulation of camel milk
}

\section{Journal Article}

\section{Author(s):}

Farah, Zakaria; Atkins, Deborah

Publication date:

1992

\section{Permanent link:}

https://doi.org/10.3929/ethz-b-000422797

Rights / license:

In Copyright - Non-Commercial Use Permitted

Originally published in:

Journal of Dairy Research 59(2), https://doi.org/10.1017/S002202990003048X 


\title{
Heat coagulation of camel milk
}

\author{
BY ZAKARIA FARAH AND DEBORAH ATKINS* \\ Laboratorium für Milchwissenschaft, Institut für Lebensmittelwissenschaft, \\ ETH-Zentrum, CH-8092 Zürich, Schweiz \\ * Ol Maisor Farm, PO Box 9, Rumuruti, Kenya
}

(Received 30 July 1991 and accepted for publication 28 October 1991)

Camel milk is an important component of the human diet in many parts of the world. It contains all essential nutrients and the composition is similar to that of cows' milk (Yagil, 1982). Present knowledge about the milk production potential of camels (Camelus dromedarius) is very limited. Data available show, however, that a camel on good feed can produce $2000 \mathrm{I}$ milk per lactation (Yagil, 1982), and even higher milk yields have been recorded (Knoess, 1980). Camel milk is drunk fresh or in the form of fermented milk. Heat processing, such as pasteurization and sterilization, as a means of preserving camel milk is unknown. Information on the heat stability of camel milk is therefore scarce. In an earlier study (Farah, 1986), camel milk was heated to 63,80 and $90^{\circ} \mathrm{C}$ for $30 \mathrm{~min}$ and the distribution of $\mathrm{N}$ between the total protein, non-casein $\mathrm{N}$ and non-protein $\mathrm{N}$ fractions was determined. The whey proteins were also examined by PAGE. The camel milk whey protein showed generally higher heat stability than that from cows' milk.

In order to study the ability of camel milk to withstand higher processing temperatures, the heat coagulation time (HCT) was determined in the range $100-130^{\circ} \mathrm{C}$ and $\mathrm{pH} 6 \cdot 3-7 \cdot 1$, and compared with measurements on cows' milk.

\section{Milk samples}

\section{EXPERIMENTAL}

Camel milk samples were taken at Ol Maisor Camel Farm, which is situated just north of the equator in Kenya's Laikipia District at an altitude of between 1767 and $1889 \mathrm{~m}$ above sea level. The animals were of indigenous breed and were fed throughout the year exclusively by grazing. The milk samples were collected from ten individual camels. The $\mathrm{pH}$ of the ten samples and that of a pooled sample were determined. The milks were then kept refrigerated at $4{ }^{\circ} \mathrm{C}$ and transported to our laboratory within $24 \mathrm{~h}$. Upon arrival, the milk samples were skimmed and analysed. For comparison, bulk cows' milk from our Zürich laboratory was used.

\section{Determination of heat stability}

Milk was adjusted to various $\mathrm{pH}$ in the range $6 \cdot 3-7 \cdot 1$ by adding $0 \cdot 1 \mathrm{M} \cdot \mathrm{NaOH}$ or $0.1 \mathrm{M}-\mathrm{HCl}$. HCT was determined in a thermostatically controlled oil bath at 100,120 and $130^{\circ} \mathrm{C}$ according to the method of Davies \& White (1966). 


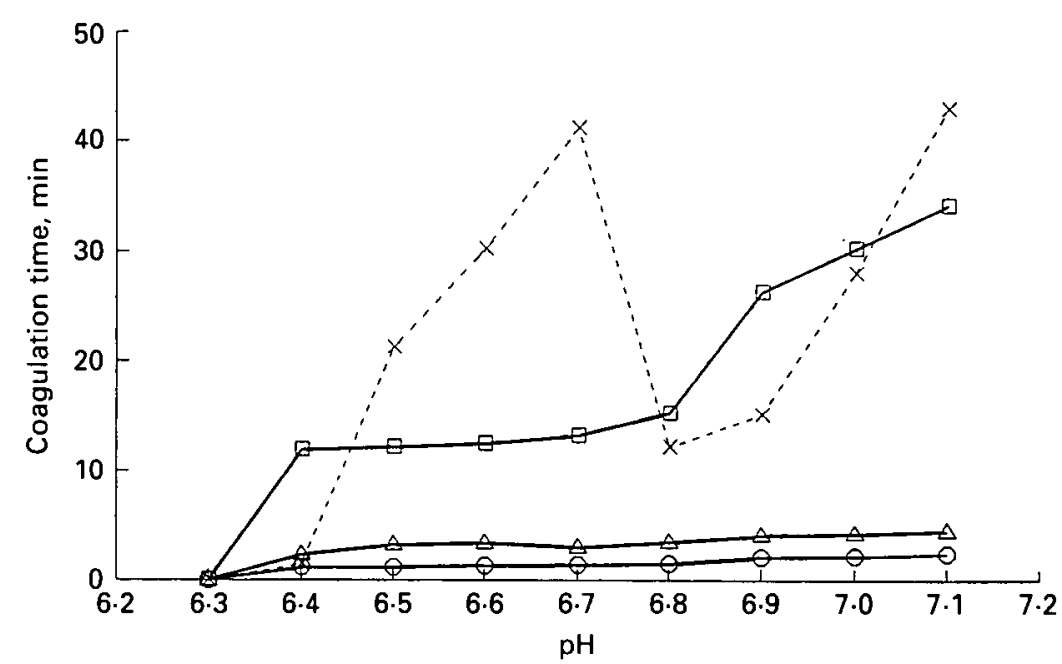

Fig. 1. Heat coagulation time-pH curves for camel milk at $\square, 100^{\circ} \mathrm{C} ; \triangle, 120^{\circ} \mathrm{C}$ and $\bigcirc, 130{ }^{\circ} \mathrm{C}$, and for cows' milk at $130^{\circ} \mathrm{C}(X)$.

\section{RESULTS AND DISCUSSION}

The heat stability of milk can be defined in terms of the time required to induce coagulation at a given temperature. For bovine milk, the most widely used temperature for heat coagulation is 130 or $140^{\circ} \mathrm{C}$. Preliminary experiments showed that in camel milk the HCT at $140^{\circ} \mathrm{C}$ was too short $(<1 \mathrm{~min}$ ) for the present assay. Coagulation times were therefore determined at 100,120 and $130^{\circ} \mathrm{C}$. Fig. 1 shows the $\mathrm{HCT}-\mathrm{pH}$ curves for pooled camel and cows' milks. All ten individual camel milk samples gave similar $\mathrm{HCT}-\mathrm{pH}$ curves.

The HCT-pH curve of cows' milk is in agreement with findings reported previously (Rose, 1963; Fox, 1982). It showed a marked maximum around $\mathrm{pH} 6.7$ and a minimum near $\mathrm{pH} \mathrm{6.8}$. The heat stability increased above $\mathrm{pH} \mathbf{6 \cdot 9}$.

The shape of the HCT-pH curve for camel milk at low temperature was different from those at high temperatures. The milks heated at 130 and $120^{\circ} \mathrm{C}$ were very unstable at all $\mathrm{pH}$ and coagulated in $2-3 \mathrm{~min}$. At $100^{\circ} \mathrm{C}$ the $\mathrm{HCT}$ initially increased with $\mathrm{pH}$, remained constant between $\mathrm{pH} 6.4$ and 6.7 and then increased progressively with increasing $\mathrm{pH}$.

Milks from different species differ in their heat stability. Compositional differences and heat-induced interaction between the caseins and whey proteins, particularly $\kappa$-casein and $\beta$-lactoglobulin, are reported to be responsible for these differences (Hoynes \& Fox, 1975; Fox \& Hoynes, 1976; Ganguli, 1979).

Casein fractions homologous with bovine $\alpha$ - and $\beta$-casein were isolated and identified by PAGE and ion-exchange chromatography (Farah \& Farah-Riesen, 1985 ; Larsson-Raźnikiewicz \& Mohamed, 1986). In these studies no protein fraction corresponding to $\kappa$-casein could be clearly detected. It is possible that camel casein contained so little $\kappa$-casein that it escaped detection or was obscured by other casein fractions.

On the other hand, four whey proteins have been isolated from camel milk: two proteins similar to serum albumin and $\alpha$-lactalbumin, and two novel milk proteins of no structural similarity to other milk proteins. The evidence for the presence of $\beta$-lactoglobulin in camel milk is conflicting (Farah, 1986; Beg et al. 1984, 1987). 
The present study found that the heat stability of camel milk differs markedly from that of cows' milk. $\kappa$-Casein and $\beta$-lactoglobulin play an important role in the stability of bovine milk. Therefore, the absence or deficiency of these two proteins in camel milk might be a cause of its poor stability at high temperatures. However, this remains to be confirmed.

\section{REFERENCES}

Bea, O. U., von Bahr-Lindström, H., Zaidi, Z. H. \& Jörnvall, H. 1984 A small camel-milk protein rich in cysteine/half-cystine. Bioscience Reports 4 1065-1070

Beg, O. U., von BaHR-Lindström, H., Zaidi, Z. H. \& Jörnvall, H. 1987 Characterization of a heterogeneous camel milk whey non-casein protein. FEBS Letters $216270-274$

Davies, D. T. \& WhiTe, J. C. D. 1966 The stability of milk protein to heat. I. Subjective measurement of heat stability of milk. Journal of Dairy Research 33 67-81

FAKaH, Z. 1986 Effect of heat treatment on whey proteins of camel milk. Milchwissenschaft $41763-765$

Farah, Z. \& Farah-Riesen, M. 1985 Separation and characterization of major components of camel milk casein. Milchwissenschaft $\mathbf{4 0} 669-671$

Fox, P. F. 1982 Heat-induced coagulation of milk. In Developments in Dairy Chemistry-1 Proteins pp. 189-228 (Ed. P. F. Fox). London: Applied Science Publishers

Fox, P. F. \& Hoy wes, M. C. T. 1976 Heat stability characteristics of ovine, caprine and equine milks. Journal of Dairy Research 43 433-442

Gaxgul, N. C. 1979 Stability of buffalo casein micelles. Journal of Dairy Research $46401-405$

Hornes, M. C. T. \& Fox, P. F. 1975 Some physico-chemical properties of porcine milk. Journal of Dairy Research 42 43-56

Knoess, K. H. 1980 Milk production of the dromedary. In Camels pp. 201-214. International Foundation for Science Provisional Report No. 6

Larsson-RaŹnikiewicz, M. \& Mohamed, M. A. 1986 Analysis of the casein content in camel (Camelus dromedarius) milk. Swedish Journal of Agricultural Research 16 13-18

Rose, D. 1963 Heat stability of bovine milk: a review. Dairy Science Abstracts $2545-52$

YaA1L, R. 1982 Camels and camel milk. Rome: Food and Agriculture Organization (FAO Animal Production and Health Paper No. 26 pp. 14-19) 